Fund, the Minister should be authorised to require from them an annual report in such form as he may order.

Your Committee have not taken any evidence as to reformatory and industrial schools, considering that these have so recently formed the subject of an inquiry by a Royal Commission, the report and recommendations of which are before Parliament. They see no reason for altering the present responsibility for workhouse schools or for the primary schools connected with the Army, the Navy, or the Marines. The responsibility for the administration of the votes for military and naval colleges do not appear to come within the reference to your Committee.

Your Committee see no reason to disturb the existing arrangements as to the supervision of the Science and Art Department.

There are various miscellaneous votes for science and art, such as those for scientific research, distributed through the Royal Society, votes for meteorology, and votes in aid of the Royal Society of Edinburgh and the Royal Irish Academy. These votes, your Committee think, should be moved by the Minister of Education, and reports, when necessary, should be made to him.

Your Committee do not propose to bring the British Museum and the National Gallery into closer relations with Her Majesty's Government than those now existing, with this exception, that, in their opinion, the Minister of Education and the Parliamentary Secretary should be ex officio trustces of each of those institutions. The President of the Council, your Committee notice, is now an ex officio trustee of the British Museum. The House of Commons would then look to the Education Department for explanations when the votes for the British Muscum and the National Gallery are discussed in Committee of Supply.

The Committee, of which the Chancellor of the Exchequer was chairman, included, among other members, Sir J. Lubbock, Mr. Salt, Mr. Raikes, Sir L. Playfair, Mr. S. Morley, Mr. Pell, Mr. Sclater-Booth, and Mr. J. Collings.

\section{THE MARINE BIOLOGICAL ASSOCIATION}

THE Council of the Marine Biological Association adopted last :-the following statements at its meeting held on July 25

\section{MEMoRANDUM No. I}

The Marine Biological Association was founded in March, $\mathbf{r} 884$, at a meeting held in the apartments of the Royal Socicty of London, Prof. Huxley, P.R.S., in the chair. Its officers and council include the leading naturalists of the country, as well as noblemen and others who took an active part in the late Fisheries Exhibition. H.R.H. the Prince of Wales has consented to be Patron of the Association, and has given evidence of the importance which he attaches to the success of its objects by contributing a handsome donation to its funds. The following is a list of the Executive of the Association :-

President : Prof. Huxley (President of the Royal Society). Vice-Presidents: The Duke of Argyll, K.G.; the Duke of Sutherland, K.G. ; the Marquis of Hamilton; the Earl of Dalhousie, K.T. ; Lord Walsingham (Trustee of the British Museum of Natural History); Prof. Allmann, F.R.S.; Sir John St. Aubyn, Bart., M.P.; Edward Birkbeck, M.P. (Chairman of the Executive Committee of the International Fisheries Exhibition); George Busk, F.R.S.; W. B. Carpenter, C.B., M.D., F.R.S.; W. II. Flower (Director of the British Museum of Natural History); J. Gwyn Jeffreys, F.R.S.; Sir John Lubbock, Bart., M.P. (President of the Linnean Society).

Council: Prof. Moseley, F.R.S. (Oxford), Chairman; C. Spence Bate, F.R.S. (Plymouth); Prof. Jeffrey Bell, F.Z.S. (British Museum) ; W. S. Caine, M.P. ; W. T. Thiselton Dyer, C.M.G., F.R.S. (Royal Gardens, Kew); John Evans, D.C.L. (Treasurer, R.S.); A. C. L. G. Günther, F.R.S. (British Museum) ; Prof. Herdman (Liverpool); E. W. H. Holdsworth ; Prof. McIntosh (St. Andrew's); Prof. Milnes Marshall (Manchester) ; Sir Philip Cunliffe Owen, K.C.M.G., C.B. ; G. J. Romanes, F.R.S. (Secretary of the Linnean Socicty); P. L. Sclater, F.R.S. (Secretary of the Zoological Society); Adam Sedgwick (Cambridge).

Hon. Treasurer: Frank Crisp (Vice-President and Treasurer of the Linnean Society), 6, Old Jewry, E.C.

Hon. Secretary : Prof. E. Ray Lankester, F.R.S., Ir, Wellington Mansions, North Bank, N.W.

The object of the Association is to erect one or more laboraories on the coast of the United Kingdom, where studies may be carried on by naturalists, leading to an improvement in zoological and botanical science, and especially to an adequate acquaintance with the food, habits, spawning, and propagation of our marine food-fishes and shell-fish.

Great scientific and practical results have been obtained in other countries, notably in the United States of America, in Germany, France, and Italy, by studies carried on through such laboratories as the Marine Biological Association proposes to erect in this country. The knowledge which can be thus and thus only gained is precisely that knowledge which is at present urgently needed in order to regulate and improve British Sea Fisheries, and it therefore seems to be not inappropriate that public bodies as well as individuals interested in the progress of natural history science should take in hand the promotion of the first attempt to institute an efficient sea-coast laboratory in these islands.

It is estimated by the Council that a sum of ro,oool. will be required to build and equip an efficient laboratory, and to insure a successful start for the Association. This sum does not include any payment to the naturalists who may conduct the operations of the laboratory, since in the first instance, at any rate, such services will be rendered gratuitously. The money which is now asked for will be expended entirely upon the laboratory, its equipment, and necessary service.

As the result of an appeal to scientific men and their immediate friends the Association has raised a sum of about 2000l. In order to obtain the rest of the money which is required it is necessary to appeal to a wider circle.

The Council of the Association feel that they have undertaken a work of national importance, and therefore confidently appeal to those who have pecuniary resources at their disposal to give them substantial aid in its realisation.

According to the bye-laws of the Association adopted at a meeting of members on June I7, I884, donors of $500 l$, to the Association become governors and permanent members of the Council of the Association. The Council hope that they may reccive some contributions of this amount or of larger sums, and would suggest that it might be found convenient by those who may intend to assign sums of large amount to the Association to do so in the form of a payment of so much a year spread over a term of years.

The donor of 100". to the Association becomes a "Founder" and life member. $\Lambda \mathrm{n}$ annual subscription of $\mathbf{r}$ l. Is., or a composition fee of $\mathbf{I}_{5} l$. I5s., is required of ordinary members. Members of the Association have the right to take part in the government of the $\Lambda$ ssociation by electing the Officers and Council at their annual meeting : they will receive the printed reports of the Association, and enjoy special privileges in the use of the laboratory and its resources.

It is intended to require an entrance fee of $5 l .5 \mathrm{~s}$. from members who join the Association later than June, I 885 .

Signed (on behalf of the Council of the Marine Biological Association),

H. N. Moseley, M.A., F.R.S., Chairman of the Council,

Linacre Professor of Anatomy in the University of Oxford July 25,1884

Memorandum No. II.-Nature of the Building, Management, and Work of the Proposed Marine Laboratory and Experimental Aquarium. - The Council of the Marine Biological Association cannot as yet definitely pledge itsclf as to details, but the following is a sketch of the nature of the building which it proposes to erect, of the probable management of the Laboratory, and of the kind of work which may be expected to be accomplished by its aid.

The most complete institution of the kind is that at Naples, which is supported by contributions from various European States, and is especially subsidised by the German Imperial Government. The buildings, fittings, and boats belonging to this institution have cost 20,000 . It is proposed to slart such an institution in this country with half this sum.

I. Building. - The first laboratory of the Marine Biological Association will probably be erected on the shore of Plymouth Sound. Plymouth is not only by its natural features one of the best possible localities for the purpose, but a Committee of the Town Council has offered to the Association a suitable site free of cost and a contribution of $1000 l$.

With regard to the building, the Council of the Marine Biological Association contemplate erecting a solid brick structure 
of about $100 \times 40$ feet ground area, and of two stories. The exterior will be simple and unpretentious. The building will be placed close to the sea-shore, so that sea water can be readily pumped into the laboratory tank, and in order that there may be easy communication with fishing-boats. It will also be desirable to have a floating barge anchored near the laboratory for special experiments on the breeding of fish, \&ce, and, in close proximity, it will be necessary to erect tanks on the foreshore, open to the tidal water, but arranged so as to prevent the escape of the animals confined in them for study.

The basement of the building will contain a reservoir tank holding several thousand gallons of sea water; on the ground floor there will be two large rooms paved with stone; one fitted with large tanks and a service of sea water, the other used for the reception and examination of a day's trawling or dredging, and also used for keeping stores and for carrying out the pickling and proper preservation of specimens to be sent, as required, to naturalists at a distance. The upper floor will be divided into a series of larger and smaller working rooms fitted with suitable tables, with reagents and apparatus required in microscopy, and with a constant supply of sea water pumped from the reservoir tank. Accommodation for ten workers will be thus provided. One of the rooms on this floor must be set apart as a library and writing room, and must contain as complete a series of works on marine zoology and botany, pisciculture, and such matters as can be brought together. The provision of such a library is one of the special conveniences which would be offered to naturalists working in the laboratory.

The building must also necessarily contain bed-room and sitting-room for a resident superintendent, and accommodation for one servant or caretaker.

2. Apparatus and Boats. - These need not at first be very extensive. Glass tanks, pumping engine and supply tubes are essential. There will be necessarily one small steam-launch for dredging in quiet weather at no great distance from shore, and a row-boat. For special expeditions larger boats or steamers could be either hired or borrowed from time to time. The local fishermen would also greatly aid the laboratory if regularly paid, and thus supplement the special boats of the Association.

3. Salaried Staff.-The Council would propose to begin work with the smallest possible number of permanent employés. These would be- $(a)$ a resident superintendent, who should be a man of fair education and some knowledge of natural history, at a salary of $\mathbf{I} 50 \%$. a year, supplemented by free quarters; $(b)$ a servant of the fisherman class, who would look after the tanks and workrooms, go out in search of specimens, and manage a boat and dredging apparatus when required. Other fishermen and boys might be hired from time to time. A sum of 100l. a year would be required for such service at the least.

4. Conditions of Admission to Use of Laboratory: Work to be done there.-The Council would propose to admit to the use of a table and other resources of the laboratory, so far as the space shall permit, any British or foreign naturalist who might make application and furnish evidence of his capability to make good use of the opportunities of the place. A preference would be given to a member of the Association, A fee might in some cases be charged for the use of a table, and other tables might be let out at an annual rental to such bodies as the Universities, this being the system adopted at Naples by Dr. Dohrn.

The Council will endeavour, when the laboratory is erected and in operation, to obtain grants of money from scientific societies, and from the Covernment, for the purpose of carrying out special investigations on a given subject, e.g., the condition affecting the fall of oyster-spat, the reproduction and general economy of the common sole, the complete determination and enumeration of the fauna and flora of the marine area adjacent to the site of the laboratory, its distribution within that area, and its relation to physical conditions. Naturalists will be nominated by the Council of the Association or by the authorities who find the money by which such naturalists are paid, to make such researches at the laboratory of the Association. When some special investigation is thus started at the laboratory, the other naturalists, who from time to time come there, will be sure to take part in the inquiry, and so help to carry it on to completion. It would be the business of the resident superintendent to facilitate this continuity of work, whilst the Council of the Association will make it a special object to bring together the results attained in the laboratory each year, in the form of a report, so as to gradually organise and direct towards definite ends the work done through its agency.
In the course of time, and with increased provision of funds for the special purpose, the Association might expect to be the means of producing -

I. A thorough knowledge of the life and conditions of the marine area adjacent to the laboratory.

2. A complete and detailed account of the natural history of certain fishes, molluscs, and crustaceans of economic importance with special reference to their increased supply.

3. Contributions to the knowledge of the growth from the egg, adult structure and physiology of such rare or otherwise scientificially interesting animals and plants as occur near the laboratory.

It is not supposed that this can be immediately accomplished by the 10,000 l. which the Association now seeks to raise. That sum will be expended in erecting the laboratory and in starting it on its career of activity. The laboratory will necessarily attract support and increased means of usefulness as, year by year, its work becomes known, and the facilities which its offers to working naturalists appreciated.

Signed (by order of the Council of the

Marine Biological Association),

July 25

E. Ray Lankester, M.A., F.R.S., Hon. Secretary

\section{THE METEOROLOGICAL CONFERENCE}

A METEOROLOGICAL conference was held at the Health Exhibition on July 17 and 18 ; the following is an abstract of the leading papers read at the conference.

Dr. J. W. Tripe read a paper of much interest on some relations of meteorological phenomena to health.

In ages long past these relations excited much attention, but the knowledge concerning them was of the vaguest kind ; and indeed, even now, no very great advance has been made, because it is only quite recently that we have been able to compare a fairly accurate record of deaths with observations taken at a number of reliable meteorological stations. The more useful and searching comparison between cases of sickness, instead of deaths, and meteorological phenomena has yet to be accomplished on a large scale in this country, and especially as regards zymotic diseases. In Belgium there is a Society of Medical Practitioners, embracing nearly the whole country, that publishes a monthly record of cases of sickness, of deaths, and of meteorological observations; but the only attempt on a large, scale in this country, which was started by the Society of Medical Officers of Health for the whole of London, failed partly from want of funds, and partly from irregularity in the returns. My remarks, which must necessarily be very brief, will refer to the relations between ( $r$ ) meteorological phenomena and the bodily functions of man, and (2) between varying meteorological conditions and death-rates from certain diseases.

As regards the first, I will commence with a few brief remarks on the effects of varying barometric pressures. A great deal too much attention is paid to the barometer if we regard it as indicating only, as it really does, variations in the weight of the column of air pressing upon our bodies, because, except at considerable elevations, where the barometer is always much lower than at sea-level, these variations produce but little effect on health. At considerable elevations the diminished pressure frequently causes a great feeling of malaise, giddiness, loss of strength, palpitation, and even nauser; and at greater heights, as was noticed by $\mathrm{Mr}$. Glaisher in a very lofty balloon ascent, loss of sight, feeling, and consciousness. These were caused by want of a sufficient supply of oxygen to remove effete matters from the system, and to carry on the organic functions necessary for the maintenance of life. On elevated mountain plateaus, or even in high residences amongst the Alps, an increased rapidity in the number of respirations and of the pulse, as well as increased evaporation from the lungs and skin, occur.

For some years past, many persons suffering from consumption, gout, rheumatism, and anemic affections have gone to mountain stations, chiefly in Switzerland, for relief, and many have derived much benefit from the change. It must not however, be supposed that diminished atmospheric pressure was the chief cause of the improvement in health, as its concomitants, viz., a diminution in the quantity of oxygen and moisture contained in each cubic foot of air, probably the low temperature, with a 